Harvard Data Science Review • Issue 3.4, Fall 2021

\title{
The Yankee Leviathan \\ Collects Statistics: Federal \\ Education Policy During \\ Reconstruction
}

\section{Andrew Donnelly}

Published on: Oct 28, 2021

DOI: https://doi.org/10.1162/99608f92.d35b59a0

License: Creative Commons Attribution 4.0 International License (CC-BY 4.0). 
Column Editors' Note: Collecting data from students and schools is one of the prime ways in which people across the globe have come to understand the impact of education. As Andrew Donnelly shows, there is nothing obvious about how to collect or interpret these numbers. By looking at the early statistics collection at the federal level in late nineteenth-century America, he argues that educational data have always been political and politicized. As a "fact-getting device," American educational statistics served from the start as a basis for larger debates about racial and regional equality, as well as a mechanism for highlighting the success of partisan policies.

Keywords: education, Civil War, reconstruction, liberalism, Garfield

After the U.S. Civil War, Black citizens demanded the expansion of public education. "The first great mass movement for public education at the expense of the state, in the South” came, W.E.B. DuBois wrote, through Black efforts to establish schools, hire teachers, and secure funding (J. Anderson, 1988; DuBois, 1935/1992; Green, 2016; Williams, 2005). Reconstruction’s national Republican leaders responded by celebrating education as the means of empowering freedpeople as citizens. But these leaders felt as constrained by constitutional limitations on federal authority as by white supremacist opposition. While the Civil War had been fought and won by a new, expanded federal bureaucracy, what has been called the 'Yankee Leviathan,' federal power during Reconstruction was beleaguered and compromised (Bensel, 1990; Downs \& Masur, 2015). Wielding tenuous federal power, Republican leaders sought a tool that would encourage states' action by cultivating states' self-interest for Black education. For the Republican Congress, that tool was the federal collection of education statistics.

Statistics, as linked to funding, remains the U.S. Department of Education's mechanism for governing education, especially since the No Child Left Behind Act of 2001 (2002) tied federal funding to a school district's performance relative to learning, attendance, and graduation standards. While George W. Bush's Department of Education penalized school districts not meeting statistical standards, Barack Obama’s department supplemented sticks with carrots of federal funding as an inducement for improved outcomes. Both administrations believed, as did the department's postbellum proponents, that education statistics for Black and White students must be collected separately and that identifying disparities would encourage the closure of gaps between student populations. When the department under Donald Trump appointee Betsy DeVos reanimated postbellum debates about states' rights (her stated goal was to “empower states” against policy_ dictated from Washington), it accompanied such efforts with reductions to the collection of education statistics by race. In doing so, DeVos attacked one rationale for the department's postbellum creation: that data would remedy racial disparities. At the same time, she implicitly acknowledged another: that education data holds political power. The postbellum politicians who created the department recognized the power of statistics and tried to use that power to improve education for Black citizens. 
These efforts were not successful. The choice to focus Reconstruction education policy on collecting statistics foreclosed other, more direct methods of supporting Black education, but Republican leaders did not make this choice in order to avoid more racially equitable outcomes. The Reconstruction Congress was earnest about racial equality. With federal education policy, they also believed in liberal governance, that the preferred legislative actions were those that did not enforce requirements but encouraged states to act right out of selfinterest. Republican leaders believed that in education statistics they had identified the perfect tool to achieve at once the principles of racial equity and limited government.

\section{Federal Education Policy in the 'Age of Statistics'}

In December 1865, Minnesota Republican congressman Ignatius Donnelly 1 proposed a national bureau that would "enforce education without regard to color" as "an essential and permanent part of any system of reconstruction” (Cong. Globe 60, 1865). Donnelly’s bill failed: it was not clear what "enforce education” meant the federal government would do, but, if it meant nationalizing education, Congress was unwilling to do it (Warren, 1974). A year later, Representative James Garfield, with the endorsement of a group of school superintendents in hand, proposed a Department of Education "for the purpose of collecting such statistics and facts as shall show the condition and progress of education in the several states and Territories" (Cong. Globe 2966, 1866). Garfield modeled his proposal after the 1862 creation of a non-Cabinet-level Department of Agriculture. A year into its existence, the Department of Education would be reduced to a bureau (and later an office) within the Department of Interior. $\stackrel{2}{2}$ The office would be relocated within the New Deal-era Federal Security Agency in 1939, then the Department of Health, Education, and Welfare in 1953, until acquiring its Cabinet-level department status in 1979. Today's department may not appear as a Civil War invention, but Garfield's initial rationale was clear: Congress's Reconstruction efforts would fail unless it made "the schoolmaster its ally” (Garfield, 1882).

Garfield is a, perhaps the, representative figure of the era’s Republican Party. An antislavery Ohioan and Union general, Garfield connects the party's abolitionist origins with its laissez faire maturity as a unified ideology. Critical of Abraham Lincoln's moderation, he voted mostly with the Radicals through the 1860s but always tempered that radicalism with a belief in limited government (Peskin, 1978). To Garfield, prohibition on "a compulsory system of education" indicated "the genius of our government” (Cong. Globe 3050, 1866)—not only did it limit federal overreach, it encouraged the self-making exemplified by his own biography. A liberal arts education had transformed the son of an impoverished widow into a college president at 25 . If that sounds like a Horatio Alger story, it became one: after Garfield's death, Alger wrote a biography, From Canal Boy to President (1881).

Central to Garfield's self-narrative, education was also his signature political issue. From his first legislative speech in 1860 defending public libraries, he advocated education both as the chief means of personal advancement and in moral terms, a choice between "the school of virtue and integrity" or that of "vice and iniquity” (Cong. Globe 3049, 1866). Among postbellum politicians, Garfield was one of the most forceful 
proponents of Black education. But his rationale was not wholly free of racial fearmongering. As president, he would justify increased federal education spending on the grounds that expanded suffrage to Black voters (who had helped elect him) was a "danger” for which there was "but one remedy": "the savory influence of universal education” (Garfield, 1883).

Garfield's belief in the power of education was matched by his belief in the power of statistics. That belief, along with his work to modernize the census and involvement in the American Social Science Association (ASSA), make him a prominent example of the 19th-century rise of statistical thinking in government and bureaucracy (Desrosieres, 2002; Porter, 1986). After establishing the Education Department, Garfield would maneuver to become chair of the congressional subcommittee on the census, and would, along with social scientists Edward Jarvis and Francis A. Walker, reform the census's statistical categories, expand its data collection, and professionalize its staff of enumerators (M. Anderson, 1988; Gorb, 1976; Nobles, 2000). In 1869, at a lecture before the ASSA's meeting in New York, Garfield declared "this is the age of statistics." He offered a positivist theory of government in which new scientific tools, namely, statistical enumeration, had rendered the world knowable in new ways. The function of government was to act upon those facts. "The legislator without statistics," Garfield said, "is like the mariner at sea without the compass. Nothing can safely be committed to his guidance” (Garfield, 1882).

But Garfield did not want action on those facts alone as much as he wanted to use those facts in service of first principles_racial equality and laissez faire economics, to name two principles Garfield mentions in his speech advocating for the department. The 1870 census, he would claim, was the most important in US history, not so much because of new statistical tools, but because emancipation had transformed society. A mariner may well be lost without his compass; with it, he is still steering the ship. One of Garfield's congressional allies, using a different metaphor in reference to data collected from Reconstruction educational efforts, supported the department so that there would be someone "to take charge of these pregnant facts" (Cong. Globe 3045, 1866).

For those creating the department, two sets of pregnant facts were most important. The military record-keeping of the Freedmen's Bureau had continued as it expanded into educational activities (Butchart, 2010). What information the bureau collected was not rates of performance relative to standards but enumeration: how many students, how many teachers, how many schools. $\underline{3}$ The most usable fact in arguments for the department was merely that the bureau had facts that could be put to use. A second, older set of statistics was rates of illiteracy collected since 1840 by census-takers who asked, “Can you read and write?” Illiterates were those adults who either said no to this question or were reported to be illiterate by a head of household. By 1870, the census split reading and writing into two questions, but the Education Department would use "can you write?” not “can you read?” as the measure of illiteracy because respondents who would "acknowledge their inability

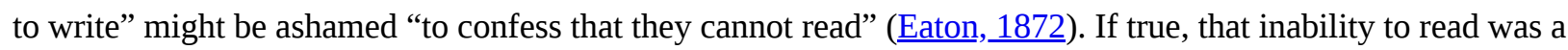
source of shame, then the publication of illiteracy rates ought to promote its own corrective action. 
This was the premise of Garfield's department with its goal of "letting in light on subjects and holding them up to the verdict of popular opinion." Statistical comparison among states would “compel” self-reform. For the underperforming states, "the very light shining upon them . . . would shame out of their delinquency all the delinquent states of the country" (Cong. Globe 3050, 1866). Michael Steudeman, who is writing a book on the educational rhetoric of the Reconstruction Congress, connects these shaming techniques to those being used by 19th-century schoolmasters to discipline aberrant pupils. These techniques, within schools and of education governance, had become possible because of a shifting focus from cultivating civic virtue to "a bird's eye view” (Steudeman, 2018). That bird's-eye view, at least from the federal government's line of sight, was not of schools but of states.

For Garfield and his allies, states—not students, schools, or districts—-were the normalizable unit of education policy. One way to view state policy disparities has been through the later concept, "laboratories of democracy,” in which states' freedom to deviate from national norms benefits innovative policy-making (Osborne, 1988). Garfield was attempting the opposite, to bring states' education activities into harmony by shaming disparities: when Tennessee saw its illiteracy rate compared to Pennsylvania, its embarrassed legislature would increase education spending. Rather than using statistics to insulate decision-making from emotions, statistics would provoke an emotional response. Another presumption was that techniques of educational discipline, such as those developed in the Math Department at the military academy at West Point to manage students' attention, would work on states (Phillips, 2015). Such presumptions represent reformers' optimism that state legislatures, especially in ex-Confederate states, would reform themselves according to a model like Massachusetts. As any teacher knows, attention, even for misbehavior, is its own reward, and certainly many states in U.S. history have defied both federal incentives and what is plainly good for them (such as the Obama-era offer of federal funding if states expanded Medicare) because of the political rewards that come with attention to their obstinacy.

Statistical shame might be a new tool, but it was a tool for an older reform strategy. Since the early 1830s, antislavery reformers had believed about slavery what temperance reformers did about alcohol and sexual reformers did about prostitution, that attention to the problem would cultivate outrage and outrage action. Garfield had been involved enough in antislavery to see that strategy work, though to a point. The painstaking documentation of slavery's abuses, in testimonial rather than statistical form, had created a Northern white abolitionist movement. That movement's success, of course, took more than attention to the problem: it took an interracial army fighting a proslavery enemy and the most significant change to U.S. law, a constitutional amendment.

To some critics, Garfield's number-collecting also needed force to achieve any educational result. "The collecting of statistics and publishing them in a book," said one congressional critic, "is not going to educate the freedmen” (Cong. Globe 3705, 1866). But to Garfield and allies, the plan perfectly combined racial equality and liberal ideology. A decentralized approach to give states such facts as to encourage self- 
improvement mirrored an education in which individuals informed of their ignorance could cultivate selfimprovement. Like liberal governance itself, the plan imagined robust social improvement through as limited governmental intervention as possible. And, like liberal governance generally, its limited design did not stop conservative opponents from calling it "a scheme of governmental control of all the common schools" (Cong. Globe 3047, 1866).

Such a scheme of direct federal control would have been different, but it was contemplated. Several European states, as frequently cited by department proponents, had nationalized education in recent decades. Radical Republicans believed that the Civil War had settled whether they lived in a nation or collection of states; during that crisis, they nationalized currency, established a national bank, conscripted a national army, and amended the Constitution to define national citizenship. In 1870, Massachusetts representative George Hoar proposed a bill to establish a national education system, but opposition was widespread from liberals worried about government overreach and Radicals worried that Southern states would redirect federal money to White and not Black students (Hoar, 1903; Lee, 1949). Others believed that Congress could take a stronger hand directing education in federally controlled areas, U.S. territories and D.C., and that publicizing statistics on these model schools could improve national education. But these efforts, too, failed in the Reconstruction Congress. In this moment when both appeared politically possible, the United States developed neither nationalized education nor model federal schools but an office to collect education statistics.

\section{The Results of a Fact-Getting Device}

The bureau's first commissioner, Henry Barnard, was by all accounts a failure. Thaddeus Stevens, the Republican legislator who at 76 was leading efforts to impeach the president, described Barnard as "a worn-out man” who merely gathered up facts (Cong. Globe 3704, 1868). Like most things Stevens hated in 1868, Commissioner Barnard was the result of that president, Andrew Johnson, whose putatively apolitical appointment of the education-journal editor was an attempt to withdraw the department from the Reconstruction fight that had inaugurated it. Barnard had been a leading education reformer since the 1830s and the driving force behind the census collecting illiteracy rates. Garfield was among those most disappointed by the report Barnard produced: 900-pages with idiosyncratic chapters like "School system of the canton of Zurich" and "the theory and experience of Oberlin College" (Barnard, 1868). One year into his presidency, Ulysses S. Grant attempted to reinstall the department within the work of Reconstruction by replacing Barnard with a decidedly political appointment, John Eaton, a Republican newspaper editor in Memphis who had served as Grant's wartime Superintendent of Freedmen.

Eaton's qualified success as commissioner may be indicated by his tenure from 1870 to 1886 across four presidencies: he neither failed too much nor succeeded too much to warrant dismissal. He actualized the department's statistical mission as set forth by the Republican Congress until replaced by a Confederate veteran appointed by Democrat president Grover Cleveland (as Cleveland frequently did with federal appointments). A biographical sketch, appended to Eaton's memoir by ghostwriter Ethel Osgood Mason, 
credited Eaton's reports for having "never degenerated into the pedantic formalism of a mere fact-getting device” (Eaton, 1907). Eaton followed Barnard in collecting information with the perspective of a global comparativist ("Progress of education in the Argentine Republic") and U.S. social analyst ("the relations of education to labor"), but he was more targeted in his collected facts and more efficient in producing reports for Congress (Eaton, 1870). He believed that his “fact-getting device” could shape opinions, teaching methods, and national policy.

Like Garfield, Eaton imagined states as the normalizable unit of his report. Such efforts were hindered at the outset by the variety in statistics each state collected. As much as he could, Eaton compared like information across states. Such tables received emphasis precisely for their normative potential. For example in Table 1, Eaton presented education spending by state; Nevada and Massachusetts topped the list at nearly \$20 per school-age child, with several ex-Confederate states all below \$1. "Should the same degree of endeavor and expense become universal in all the States, cities, and country districts," Eaton concluded, "how vast, compared with other countries, how satisfactory, would be the result to American patriotism.” Despite low levels of spending in Southern states, Eaton tried to demonstrate the success and continued need for Reconstruction efforts. In this way, the report served a political function of which Garfield had been cognizant: publicizing the benefits of Republican policies. 
Table 1. Per-School-Age Pupil Spending by State. Eaton sought to harmonize state education spending by presenting disparities. From Eaton (1870).

Graduated table, shosoing the amount expended by the different States for the education of each child, of their school age, fo.

\begin{tabular}{|c|c|c|c|c|}
\hline$\frac{\stackrel{5}{E}}{\text { 至 }}$ & Statee. & 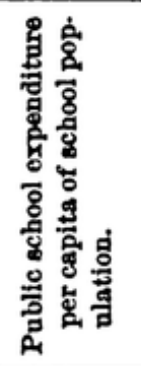 & 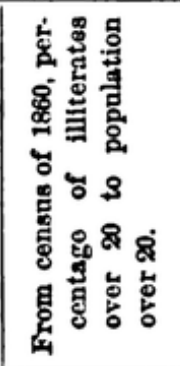 & 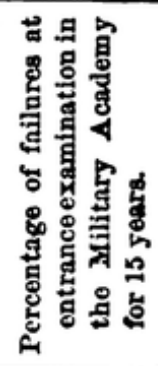 \\
\hline $\mathbf{1}$ & Neveda .......... & 19. $17+$ & & $.85+$ \\
\hline 2 & Masaschuretts. & 16. $45+$ & 6.55 & $.02+$ \\
\hline 3 & California .............. & 11. $44+$ & 7.56 & .20 \\
\hline 4 & Connecticist............ & $10.20+$ & 3. 29 & $.27+$ \\
\hline 5 & Ptonsylvania ........... & 7. $86+$ & 5.68 & $.15+$ \\
\hline 6 & Illinois.............. & 7. $83+$ & 7. 37 & $.12+$ \\
\hline$i$ & Iowa................... & 7. $21+$ & C. 26 & $.16+$ \\
\hline $\mathrm{e}$ & New York ............. & 6. $83+$ & 5.81 & $.15+$ \\
\hline 3 & Vermont......... & 6. 47+ & 5. 09 & $.07+$ \\
\hline 10 & 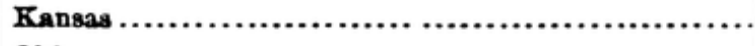 & 6. 45- & 5. 88 & .50 \\
\hline 11 & Ohio ............. & 6. 43+ & 5. 74 & .25 \\
\hline 12 & Michigan ............... & 6. 40+ & 4.99 & $.27+$ \\
\hline 13 & New Jersey ............................ & 6. $38+$ & 6.58 & $.03+$ \\
\hline 14 & Rhode Island...$\ldots \ldots \ldots \ldots \ldots \ldots \ldots$ & 6. $20+$ & 6.07 & .00 \\
\hline 15 & Minnesota $\ldots \ldots \ldots \ldots \ldots \ldots \ldots$ & 5. $71-$ & 5.67 & $.18+$ \\
\hline 16 & Wisconsin $\ldots \ldots \ldots \ldots \ldots \ldots \ldots \ldots \ldots \ldots \ldots \ldots \ldots$ & 4. $98+$ & 4. 52 & $.18+$ \\
\hline 17 & 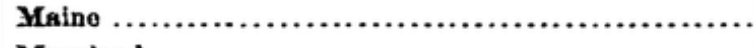 & 4. $78+$ & 2.92 & $.15+$ \\
\hline 13 & Maryland .......... & $* 4.50+$ & 22. 10 & $.15+$ \\
\hline 19 & 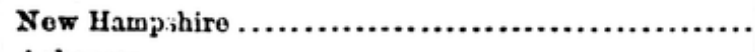 & 4. $46+$ & 2.46 & $.07+$ \\
\hline $\mathbf{3 0}$ & Arkansas ......... & 3. $97+$ & 39.42 & .20 \\
\hline 21 & 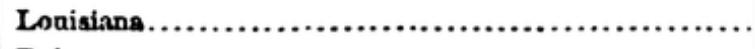 & $284+$ & 53. 25 & $.16+$ \\
\hline 22 & Delaware ......... & $12.70+$ & 25.30 & $.45+$ \\
\hline 23 & Miseouri ............ & 2. $65+$ & 19. 76 & $\cdot .31+$ \\
\hline 24 & Nebraska... & $2.65+$ & 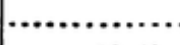 & .20 \\
\hline 25 & Indians............ & $2.37+$ & 10.41 & $.28+$ \\
\hline $\mathbf{9 6}$ & Alabama......... & $1.49+$ & 54.61 & $.34+$ \\
\hline 27 & Tennessee .......... & $.91+$ & 38.09 & $.25+$ \\
\hline 98 & Florida ....... & $\$ 91+$ & 52.53 & .00 \\
\hline $\boldsymbol{2}$ & 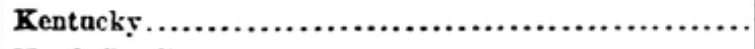 & $.60+$ & 31.61 & $.28+$ \\
\hline 30 & 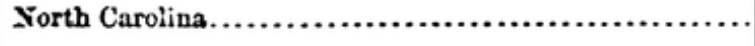 & $.48+$ & 47. 34 & $.18+$ \\
\hline
\end{tabular}

- School population from United States census of 1860; school expenditure of 1868. + School population from Uuited States censns of 1 1560 ; school expendituro of 1869-'70. : School population from Cnited Statcy consus of 1860; school oxpenditure of 1869.

Sore.-The school expenditure in the States of Oregon and South Carolina, tho school expendituro and achool population in the States of Georgia, Teras, and Virginia, and the school population of Weat Virginia_are not ascertainable by reporte. 
A decade into his commissionership, Eaton was reappointed by the man who had first proposed the office. During that time, Eaton's work had convinced him of the need to accompany data collection with national funding. President Garfield agreed and, in his inaugural address, made the case for federal education funding. The president's first 120 days were consumed by fights over executive appointments, a Supreme Court nomination, and Latin American trade negotiations; on the 121st, he was shot. He languished for 3 months and died in September 1881. New Hampshire senator Henry Blair took up the martyred president’s cause, proposing a bill for federal funding to states and schools proportionate to rates of illiteracy. To make his case, Blair used census statistics on illiteracy prepared by Eaton's department. Departmental aid was doubly limited, with Blair stating, "these tables represent an indescribable amount of my personal work and weariness, and I may overestimate their importance” (Blair, 1887). Nonetheless, Blair's efforts represented the application of the department's statistical thinking. The Senate passed Blair's bill three times between 1884 and 1890 but it failed in the House, making it, at best, the legislation that failed to be born from all the collected pregnant facts (Jenkins \& Peck, 2021).

Even without Blair's federal funding, education systems did become more harmonized by the 20th century. This was due less to the department than other forces of normalization by which teachers became professionals, school districts the agents of state welfare, and curricula the means to Americanize recent immigrants and train students in the cultural norms of work (Groeger, 2021). Normalized schools, however, did not achieve the initial goal of improved education for Black students. The question persists today: who will compel the legislature of a state like Mississippi to provide basic levels of funding to its majority-Black public schools? In 2015, voters tried to do so through a statewide referendum. But the Republican-dominated legislature manipulated the ballot to include an alternative, weaker amendment and a prerequisite question "For Approval of Either" amendment. Eighty percent of voters supported one of the two amendments in the second question (47\% to 33\% for the stronger), but 52\% voted "Against” when asked whether they approved "Either," denying both amendments (Dreher, 2015). Perhaps state legislators need to see more accurate and finely tuned data. Or perhaps the federal government needs stronger tools, not of statistical encouragement but of enforcement.

\section{Disclosure Statement}

Andrew Donnelly has no financial or non-financial disclosures to share for this article.

\section{References}

Alger, H. (1881). From canal boy to president, or the boyhood and manhood of James A. Garfield. DeWolfe.

Anderson, J. (1988). Education of Blacks in the South, 1860-1935. UNC Press.

Anderson, M. (1988). The American census: A social history. Yale University Press. 
Barnard, H. (1868). Report of the commissioner of education with circulars and documents accompanying the same. U.S. Government Printing Office. https://babel.hathitrust.org/cgi/pt?id=hvd.32044030496962

Bensel, R. (1990). Yankee leviathan: The origins of central state authority in America, 1859-1877. Cambridge University Press.

Blair, H. (1887). The education bill. American News Co.

Butchart, R. (2010). Schooling the Freedpeople: Teaching, learning, and the struggle for Black freedom, 18611876. UNC Press.

Congressional Globe, 39th Cong., 1st Sess. (December 4, 1865-July 28, 1866).

https://memory.loc.gov/ammem/amlaw/lwcglink.html\#anchor39

Congressional Globe, 40th Cong., 2nd Sess. (December 2, 1867-November 10, 1868).

https://memory.loc.gov/ammem/amlaw/lwcglink.html\#anchor40

Desrosieres, A. (2002). The politics of large numbers: A history of statistical reasoning (C. Naish, Trans). Harvard University Press.

Downs, G., \& Masur, K. (2015). Introduction. In G. Downs \& K. Masur (Eds.), The world the Civil War made (pp. 1-21). UNC Press.

Dreher, A. (2015, November 11). The demise of Initiative 42. Jackson Free Press. https://www.jacksonfreepress.com/news/2015/nov/11/demise-initiative-42/

DuBois, W.E.B. (1992). Black Reconstruction in America, 1860-1880. Free Press. (Original work published 1935).

Eaton, J. (1870). Report of the commissioner of education made to the Secretary of the Interior for the year 1870. U.S. Government Printing Office. https://babel.hathitrust.org/cgi/pt?id=uc1.b3970367

Eaton, J. (1872). Report of the Commissioner of Education. In Report of the Secretary of the Interior (Vol. II). U. S. Government Printing Office. https://books.google.com/books?id=-FY6AQAAMAAJ

Eaton, J., with Mason E. (1907). Grant, Lincoln, and the Freedmen: Reminiscences of the Civil War. Longmans.

Garfield, J. (1882). The works of James Abram Garfield (B. A. Hinsdale, Ed.; Vol. I). Osgood. https://books.google.com/books?

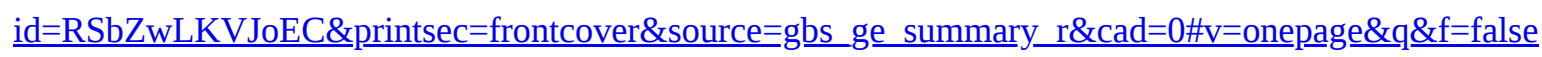


Garfield, J. (1883). The works of James Abram Garfield (B. A. Hinsdale, Ed.; Vol. II). Osgood. https://books.google.com/books?

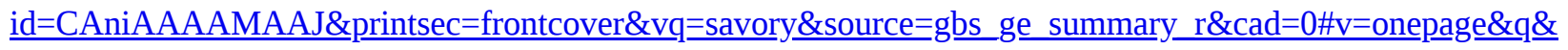
$\underline{\mathrm{f}=\mathrm{false}}$

Green, H. (2016). Educational reconstruction: African American Schools in the Urban South, 1865-1890. Fordham University Press.

Grob, G. (1976). Edward Jarvis and the federal census. Bulletin of the History of Medicine, 50(1), 4-27.

Groeger, C. (2021). The education trap. Harvard University Press.

Hoar, G. (1903). Autobiography of seventy years. Scribner’s Sons.

Jenkins, J., \& Peck, J. (2021). The Blair Education Bill: A lost opportunity in American public education. Studies in American Political Development, 35(1), 146-170. https://doi.org/10.1017/S0898588X20000085

Lee, G. C. (1949). The struggle for federal aid, first phase. Bureau of Publications, Teachers College, Columbia University.

Nobles, M. (2000). Shades of citizenship: Race and the census in modern politics. Stanford University Press.

Osborne, D. (1988). Laboratories of democracy. Harvard Business School Press.

No Child Left Behind Act of 2001, Pub. L. No. 107-110, 20 U.S.C. (2002).

https://www.govinfo.gov/content/pkg/PLAW-107publ110/pdf/PLAW-107publ110.pdf

Peskin, A. (1978). Garfield. Kent State University Press.

Phillips, C. (2015). An officer and a scholar: Nineteenth-century West Point and the invention of the blackboard. History of Education Quarterly, 55(1), 82-108. https://doi.org/10.1111/hoeq.12093

Porter, T. (1986). The rise of statistical thinking, 1820-1900. Princeton University Press.

Steudeman, M. (2018). From civic imperative to bird's-eye view: Renegotiating the idioms of education governance during the Reconstruction Era. History of Education Quarterly, 58(2), 199-228.

https://doi.org/10.1017/heq.2018.3

Warren, D. (1974). To enforce education: A history of the founding years of the United States Office of Education. Wayne State University Press.

Williams, H. (2005). Self-taught: African American education in slavery and freedom. UNC Press. 
(C2021 Andrew Donnelly. This article is licensed under a Creative Commons Attribution (CC BY 4.0) International license, except where otherwise indicated with respect to particular material included in the article.

\section{Footnotes}

1. No relation to the author. $\subseteq$

2. Even U.S. Senators in the 1860s could not keep track of the distinctions between bureau, office, and department, and often used these titles as interchangeable. Radical Republican senator Charles Sumner, who said he would have been for a Cabinet-level commissioner, urged his colleagues not to get caught up in terminological debates: "Call it then I say a bureau or call it a department; but give us the bill and do not endanger it” (Cong. Globe 1483, 1866). $ヒ$

3. Much of the Freedmen's Bureau data is digitized or available as microfilm images through genealogy_ databases. $\triangleq$ 